\title{
Effects of Strategic Direction on the Performance of Africa Inland Church Theological Training Institutions in Kenya
}

\author{
Munyao, Solomon. M. ${ }^{1}$, Chiroma, Nathan. H. (PhD) ${ }^{2}$ \& Ongeti, Walter. J. (PhD) ${ }^{3}$ \\ ${ }^{1}$ School of Leadership, Business and Technology, Pan Africa Christian University, P.O. Box 56875-00200, Nairobi \\ ${ }^{2}$ School of Theology, Pan Africa Christian University, P.O. Box 56875-00200, Nairobi \\ ${ }^{3}$ School of Leadership, Business and Technology, Pan Africa Christian University, P.O. Box 56875-00200, Nairobi
}

DOI: $10.29322 /$ IJSRP.10.03.2020.p9939

http://dx.doi.org/10.29322/IJSRP.10.03.2020.p9939

\begin{abstract}
Christian organizations such as theological training institutions are started with the aim of achieving certain objectives. For example, one of the objectives of Africa Inland Church (A.I.C) theological training institutions is to equip men and women who have been called by God with the necessary biblical and leadership skills to minister in the church. This will result in the conversion of more people to Christ and the spread of the gospel in preparation for Jesus' second coming. However, previous research studies had indicated that majority of theological training institutions and especially in Africa had not been adequately preparing church leaders for this noble task. Some of the reasons for this failure has been inadequate curriculum, lack of financial support from donors, declining number of students who are joining theological training institutions and styles of leadership. This study was anchored on strategic direction which is an aspect of strategic leadership. Data was collected using both open and closed ended questionnaires from management members, employees and third year students of A.I.C theological training institutions in Kenya. The study established that strategic direction had a positive effect on the performance of A.I.C theological training institutions in Kenya with a correlation of $r=0.465$, a $\beta$ value of 0.465 , a significance of $F=25.349$ and that it explained 21.6 percent $\left(\mathrm{r}^{2}=.216\right)$ of the variability of organizational performance. This study is necessary because the performance of theological training institutions is not known in the Kenyan context. The study recommends that top leaders of Africa Inland Church theological training institutions be strategic as they leading their organizations into the volatile business environment.
\end{abstract}

Index Terms- Strategic leadership, strategic direction, organizational performance.

\section{INTRODUCTION}

$\mathrm{C}$ hristian organizations such as theological training institutions are started with the aim of achieving certain objectives. For example, one of the objectives of Africa Inland Church (A.I.C) theological training institutions is to equip men and women who have been called by God with the necessary biblical and leadership skills to minister in the church. This will result in the conversion of more people to Christ and the spread of the gospel in preparation for Jesus' second coming. However, previous research studies had indicated that majority of theological training institutions and especially in Africa had not been adequately preparing church leaders for this noble task. Some of the reasons for this failure has been inadequate curriculum, lack of financial support from donors, declining number of students who are joining theological training institutions, and styles of leadership. This study was anchored on strategic direction which is an aspect of strategic leadership.

In order to ensure that organizations continue to perform in their area of expertise in this era in which change is the only constant, they need strategic leaders who are proactive in visualizing the future and putting in place proper mechanisms to achieve the planned objectives (Ng'ang'a, 2018). While emphasizing the important role of leadership in organizational success, Mwambazambi (2014) mentioned the issue of leadership as being a very important one because individual and socialpolitical success depends on whether good or bad leadership is exercised. Furthermore, without effective leadership, everything that people do is likely to fail but with effective leadership, the future is constantly created a new for the people and community. Folarin (2013) explained visionary leadership which is an aspect of strategic leadership as one of the major and serious problems facing the African Continent in the $21^{\text {st }}$ century. Further, organizational performance as a result of such factors as reducing number of students is a real challenge facing organizations such as Universities as evidenced by the recent call by the Cabinet Secretary for Education to merge some Universities and close others in Kenya (Omanga, 2019).

Organizational performance has been an area of concern for many years and especially due to the current turbulent business environment. In a previous study, Mutuku (2014) found out that many organizations were finding it difficult to achieve their set objectives in the current business environment characterized by uncertainty and economic instability. This is the reason therefore, why the concept of organizational performance has received substantial attention in the professional discourse as is evidenced by the quality and quantity of both the empirical and theoretical literature on the subject (Ng'ang'a, 2018). For Ivancevich, Konopake, and Matteson (2014), some of the factors that have been hindering organizations from achieving optimum performance are globalization, advancement in technology, styles of leadership and the speed of change and innovation Similarly, 
Mumo (1997), Nkonge (2013) and Naidoo (2015) explained that despite the vital role of leadership in organizational performance, previous studies indicated that in the past, some organizations had underperformed due to ineffective strategic leadership.

\section{Statement of the Problem}

The motivation behind carrying out of this study was the poor performance of organizations in Kenya as a result of various reasons. For example, the results of previous studies by Mumo (1997) and Nkonge (2013) in A.I.C and Anglican Church of Kenya (A.C.K) theological training institutions respectively showed that these institutions were facing performance problems. Specifically, the results of the two studies cited globalization, inadequate curriculum, dropping number of students joining theological training intuitions, lack of donor funding, poor utilization of resources, inadequately prepared graduates and styles of leadership as some of the problems facing theological training institutions belonging to the two denominations. With these challenges, A.I.C theological training institutions require leaders who are able to set the strategic direction of their organizations for them to survive in the current turbulent business environment where stakeholders are demanding value for their money and change being the only constant. However, previous research studies point out to the fact that strategic leaders have had a challenge when it comes to establishing the strategic direction of their organizations (Ng'ang'a, 2018).

Establishing the strategic direction of an organization is one of the real challenge facing strategic leaders. According to a United Nation-Habitant Annual Report (2016), ineffective strategic leadership has been exemplified by a general lack of organizational flexibility in the wake of operating environmental changes and poor communication on strategic direction across the organization. These sediments were echoed by Kabetu and Iravo (2018) when they wrote that strategic leadership does not come easy in most organizations. For instance, in their previous study, statistics showed that fewer than 10 percent of leaders exhibit strategic skills which is a woefully number considering the demands on organizations today. The need for leaders to establish strategic direction has been made necessary by the fact that organizations live into the future besides the many changes occurring in the world today that calls for leaders to have a strategic foresight. Thus it is from this standpoint and taking into consideration that organizations require different styles of leadership for effectiveness (Van Vart, 2014) that this study sought to explore how strategic direction approach can be a viable option for effective administration of A.I.C theological training institutions in Kenya for optimum performance.

\section{STRATEGIC DiRECTION}

One of the key responsibilities of strategic leaders entails setting the direction that an organization will take through the development of vision, mission, and core values (Ng'ang'a (2018). Bryson (2004) explained strategic direction as an aspect that help leaders in organizations to be orderly and strategic as they lead their organizations on a daily basis. Okibo and Masika (2012) opined that the role of strategic leaders does not end with the setting of strategic direction because is also entails monitoring the process of implementing the set strategic plans. In the same way, strategic direction entails developing the vision, mission, strategic goals and objectives of an organization as alluded by Mutia (2015). The process further involves drawing a roadmap for the organization's future through a smooth development of a strategic plan. Szpakowski (2011) expounded that through the development of a strategic plan, a leader aligns the actions, beliefs, values of employees and management as well as stakeholders towards the organizational goal resulting in improved performance as explained by Odita and Bello (2015). This therefore suggests that without a strategic direction, an organization will be like an airplane flying without a navigational compass. Some of the elements of strategic direction are vision, mission, values and objectives.

\subsection{Vision}

Vision can be defined as the mental picture of what does not exist now but will exist in the future. Ozdem (2011) pointed out that a good vision should capture where and what the firm wants to be in future and the level it wants to attain in terms of performance. Similarly, Thompson, Peterraf, Gamble, Stickland and Jain (2013) explained strategic vision as the top managements' perspective about the company's long-term direction and determines the type of customers and products that the organization will be targeting. Joachim (2010) defined vision as a mental picture of the state of an organization developed through creative imagination and foresightedness of its leaders. Essentially, a vision serves various purposes such as giving direction, acting as a point of reference, and indicating where the organization is going and probably why it is going there (Populova, 2014). An effective vision is challenging and stimulating for the organization, attracts commitment, energizes people, creates meaning in workers besides linking the present with the future aspirations of the organization (Ng'ang'a, 2018). A previous research study on private Universities in Kenya indicated that vision contributed positively to the performance of such Universities (Jonyo, Ouma \& Mosoti, 2018). In order for A.I.C theological training institutions to continue achieving their objectives, they need to have leaders with a clear vision of where they are taking the institutions.

\subsection{Mission}

After formulating a vision, it is important for an organization to clearly stipulate its mission which in essence briefly explains how the vision will be achieved. As Ng'ang'a (2018) opined, mission is the context in which strategies are created by organizations and aligned to both its present and future directions. Agwu (2015) postulated that the purpose of a mission is to explain how to get where the organization want to be in future. Additionally, it describes the clients, major processes and informs the organization about the desired level of performance. A mission is an expression of what leaders in an organization perceive as the key objective of being in business (Kirk \& Nolan, 2010). Previous research studies indicate that there was a positive correlation between mission and organizational performance (Jonyo, Ouma, \& Mosoti, 2018). The future continual performance of A.I.C theological training institutions will to a 
large extend depend on how well strategic leaders will be able to clearly articulate their mission.

\subsection{Core Values}

The purpose of core values is to link the vision and mission of an organization and further portrays the environment in which the latter will be implemented. Thompson, Peterraf, Gamble, Stickland and Jain (2013) defined core values as the beliefs, traits and behavioral norms that leaders in organizations determine should guide the pursuit of its vision and mission. Further, an organization is said to have strong value system when members share common values related to organization's strategic direction. While elaborating on the role of core values, Thompson, Peteraf, Gamble and Strictland (2012) wrote that the management use core values to guide the organization in pursuit of its vision and mission. A study by Kirkpatrick (2017) showed that core values played a critical role in the performance of organizations. On the contrary, results from previous studies indicated that some core values have been found to be associated with high organizational performance more than others because of their impact on employees' behavior.

\subsection{Objectives}

Without objectives, vision, mission, and core values are not enough by themselves to enable an organization to achieve positive results in the business it is undertaking. In this regard, Thompson, Peterraf, Gamble, Stickland and Jain (2013) explained that, "the managerial purpose of setting objectives is to convert the vision and mission into specific performance targets" (p. 31). These authors add that a firm's objectives focus efforts and align actions throughout the organization, serve as yardsticks for tracking a company's performance and progress and provide motivation and inspire employees to greater levels of effort. There is sufficient evidence that setting of objectives in an organization increases its performance. For instance, in their research study, Wheelen and Hunger (2012) discovered that the achievement of corporate objectives results in the fulfilment of a corporation's mission.

\section{ORGANIZATIONAL PERFORMANCE}

Since organizations are started for the purpose of achieving specific objectives, the measurement of their performance becomes a critical factor. According to Gusmao, Christiananta and Ellitan (2018), organizational performance is the total performance results achieved by an organization in accordance with its mission. In fact, measuring performance involves determining whether an organization's inputs can be matched with its outputs. On their part, Ivanov and Avasilcai (2014) wrote that in recent years and because of the dynamism of the environment where organizations compete, more and more organizations have developed a considerable interest for performance measurement. They add that some of the performance methods that previous researchers have used are Malcolm Baldrige model, the Performance Prism, European Foundation for Quality Management model, and the Balanced Scorecard (BSC) that this study adopted.

The BSC that has its focus of four performance perspectives was developed by Kaplan and Norton (Kaplan \& Norton (2007).
These perspectives are financial, customer, processes and learning and growth. According to Kairu, Wafula, Okaka and Akerele (2013), customer perspective measures the capability of the company to provide customers with quality services and products including efficiency of delivery and customer satisfaction. These authors further explained that it is the critical process to achieve both the financial and customer perspectives in an organization because it helps in identifying the key business processes in which the organization will achieve its objectives. Massingham, Massingham and Dumay (2019) posited that learning and growth perspective focus on how employees can improve themselves and create more value to the organization. In their research study, Pandian and Narendran (2015) found a positive correlation between financial factors and profitability of textile industries in India while Suchanek and Kralova (2015) found a positive correlation between customer satisfaction and organizational performance. Results of a research study by Namin and Ebrahimpour (2015) showed that internal processes had a positive correlation on non-commercial performance at Imam Khomeini Committee in Iran. The results of a previous research study by Ankrah (2017) indicated that employee training, which an aspect of learning and growth has a positive impact on employee performance.

\subsection{Strategic Direction and Organizational Performance}

One of the key responsibilities of strategic leaders entails setting the direction that an organization will take through the development of vision, mission, core values and objectives/goals (Ng'ang'a, 2018; Mutia, 2015). The process further involves drawing a roadmap for the organization's future through a smooth development of a strategic plan. Strategic direction is an aspect that help leaders in organizations to be orderly and strategic as they lead their organizations on a daily basis (Bryson, 2004). Through the development of a strategic plan, a leader aligns the actions, beliefs, values of employees and management as well as stakeholders towards the organizational goal resulting in improved performance (Szpakowski, 2011; Odita \& Bello, 2015). The role of strategic leaders does not end with the setting of strategic direction because it also entails monitoring the process of implementing the set strategic plans (Okibo \& Masika, 2014). This therefore suggested that without a strategic direction, an organization will be like an airplane flying without a navigational compass.

The fact that determining the strategic direction of an organization is one of the key components of strategic leadership that impacts organizational performance had made scholars to study the relationship between the two variables. Majority of these studies had shown a positive correlation between vision, mission, core values and objectives on organizational performance. In a previous study targeting private Universities in Kenya, the results indicated that vision contributed positively to the performance (Jonyo, Ouma \& Mosoti, 2018). These authors further asserted that there existed a positive correlation between mission and organizational performance. A study by Kirkpatrick (2017) showed that core values played a critical role in the performance of organizations. Kwenin, Muathe and Nzulwa (2013) investigated the influence of employee rewards, job satisfaction and human resource policies on employee retention in Vodafone Ghana Limited. The results indicated that job satisfaction and 
favorable human resource policies significantly impacted employee retention and consequently organizational performance.

\section{Methodology}

This study employed the descriptive survey design. Data was collected from Management members, employees, and third year students of A.I.C theological training institutions in Kenya using both closed and open ended questionnaires. The three A.I.C theological training institutions were selected using purposeful sampling method while the Management members, employees and students were selected using stratified random sampling method. Out of a target population of 1221, 120 respondents were selected based on the 10 percent rule. Questionnaires were distributed using research assistants and hand delivery. Out the 120 questionnaires that were distributed, 94 questionnaires were returned representing a response rate of 78.3 percent. Once data was received from the field, it was cleaned, coded, and entered into a SPSS software before it was analysed and results presented.

\section{RESULTS}

Various statements were presented to the respondents and requested to indicate to what extent they agreed with them based on the five Likert Scale where 1 is "Strongly Disagree" and 5 is "Strongly Agree" as shown in table 1 below. The results indicated that among the statements that were presented to respondents, the statement that "This institution had a clear mission" had the highest mean as well as the highest standard deviation indicating that although majority of the respondents agreed with this statement, the responses were not concentrated around the midpoint. The statement that had the least mean as well as the least standard deviation was "This institution has clear values" which meant that majority of the responses were concentrated around the md point.

In table 2 , the results of the correlation analysis between strategic direction and organizational performance indicated that indeed there existed a positive correlation between the two variables $(0.465)$

In table 3, 4 and 5 below, the regression analysis results indicated that the power as explained by the change of the dependent variable (organizational performance) and independent variable (strategic direction) was 0.216 . This therefore meant that 21.6 percent of the organizational performance at A.I.C theological training institutions was explained by strategic direction with the remaining 78.4 percent being explained by other variables. In terms of the significant of the model, the F-value was found to be relatively significant at 25.349. Additionally, the results indicated that the correlation coefficient between strategic direction and organizational performance was positive at 0.465 . Since p-value was less than 1.0, the hypothesis was rejected because the confidence level of the model was over 95 percent. In terms of the effects of strategic direction on organizational performance determined by beta, the results indicated a $\beta$ value of .465 which is a positive effect. This therefore implied that an increase in strategic direction resulted in an increase in organizational performance.

Table 1: Descriptive analysis of strategic direction

\begin{tabular}{llllll}
\hline & $\mathrm{N}$ & Minimum & Maximum & Mean & Std. Deviation \\
\hline $\begin{array}{l}\text { This institution has a clear vision 94 } \\
\text { This institution has a clear mission94 }\end{array}$ & 2 & 5 & 4.47 & .683 \\
$\begin{array}{l}\text { This institution has clear core } \\
\text { values }\end{array}$ & 1 & 5 & 4.56 & .649 \\
$\begin{array}{l}\text { This institution has clear } \\
\text { objectives/goals }\end{array}$ & & 2 & 5 & 4.45 & .757 \\
Valid N (listwise) & 94 & & 5 & 4.54 & .728 \\
\hline
\end{tabular}

Source (Field Data)

Table 2: Correlation analysis - Strategic direction and organizational performance

\begin{tabular}{llll}
\hline \multirow{3}{*}{ Strategic Direction } & Pearson Correlation & 1 & $.465^{* *}$ \\
& Sig. (2-tailed) & & .000 \\
& $\mathrm{~N}$ & 94 & 94 \\
& Pearson Correlation & $.465^{* *}$ & 1 \\
Organizational Performance & Sig. (2-tailed) & .000 & \\
& $\mathrm{~N}$ & 94 & 94 \\
\hline
\end{tabular}


**. Correlation is significant at the 0.01 level (2-tailed).

Source (Field Data)

Table 3: Model Summary - Strategic Direction and Organizational Performance

\begin{tabular}{lllll}
\hline Model & R & R Square & Adjusted R Square & Std. Error of the Estimate \\
\hline 1 & $.465^{\mathrm{a}}$ & .216 & .207 & 7.288 \\
\hline
\end{tabular}

a. Predictors: (Constant), Strategic Direction

Table 4: ANOVA ${ }^{a}$

\begin{tabular}{lllllll}
\hline Model & & Sum of Squares & Df & Mean Square & F & Sig. \\
\hline \multirow{1}{*}{1} & Regression & 1346.478 & 1 & 1346.478 & 25.349 & $.000^{\mathrm{b}}$ \\
& Residual & 4886.841 & 92 & 53.118 & & \\
& Total & 6233.319 & 93 & & & \\
\hline
\end{tabular}

a. Dependent Variable: Organizational Performance

b. Predictors: (Constant), Strategic Direction

Table 5: Coefficients ${ }^{a}$

\begin{tabular}{|c|c|c|c|c|c|c|}
\hline \multirow[t]{2}{*}{ Model } & & \multicolumn{2}{|c|}{ Unstandardized Coefficients } & Standardized & \multirow[t]{2}{*}{$\mathrm{T}$} & \multirow[t]{2}{*}{ Sig. } \\
\hline & & B & Std. Error & Beta & & \\
\hline \multirow{2}{*}{1} & (Constant) & 24.476 & 6.092 & & 4.017 & .000 \\
\hline & Strategic Direction & 1.689 & .335 & .465 & 5.035 & .000 \\
\hline
\end{tabular}

a. Dependent Variable: Organizational Performance

\section{CONCLUSION}

The unpredictable business environment in which organizations are operating in today has made the setting of organizational strategic direction and the measurement of performance a necessity and not an option. Further, results of previous studies indicate that many organizations had been facing performance challenges in the hands of leaders who are unable to shape their future destiny. Some of the challenges are declining number of students, declining financial support from donors, and poor utilization of resources among others. These challenges calls for leaders who are able to set the strategic direction of their organizations in order to continue achieving their objectives. The four aspects of strategic direction are vision, mission, core values and objectives which have all been proven to have a positive effects of organizational performance in A.I.C theological training institutions. The results of this study confirms the results of previous studies that indeed strategic direction has a positive effect of organizational performance.

\section{REFERENCES}

[1] Agwu, M. E. (2015). Lecture note on advanced strategic management. Covenant University, Ota, Ogun State: Unpublished.

[2] Ankrah, D. (2017). Assessing the impact of training and development on employee performance in the tertiary education sector of Ghana: A case study of the University of Energy and Natural Resources, Sunyani. Journal of Energy and Natural Resource Management, 4(1), 70-80.

[3] Bryson, J. M. (2004). Strategic planning for public and non-profit organizations (3rd ed). San Francisco: Jossey-Bass.

[4] Folarin, S. (2013). Africa's leadership challenges in the 21st century: A Nigerian perspective. African Journal of Political Science and International Relations, 7(1), 1-11.
[5] Gusmao, F. D., Christiananta, B., \& Ellitan, L. (2018). The influence of strategic leadership and organizational learning on organizational performance with organizational behaviour as an intervening variable. International Journal of Scientific Research and Management, 6(4), 124-131.

[6] Ivancevich, J.M., Konopake, R., \& Matteson, M. T. (2014). Organizational behavior and management (10th ed.). New York, NY: McGraw-Hill.

[7] Ivanov, C., \& Avasilcai, S. (2014). Performance measurement models: An analysis for measuring innovation processes performance. Journal of Social and Behavioral Sciences, 24(1), 397-404.

[8] Joachim, A. (2010). Interface between corporate vision, mission, and production and operation management. Global Journal of Management and Business Research, 10(2), 18-22.

[9] Jonyo, B. O., Ouma, C., \& Mosoti, Z. (2018). The effect of mission and mission on organizational performance within private universities in Kenya. European Journal of Educational Sciences, 5(1), 15-33.

[10] Kabetu, D. G., \& Iravo, M. A. (2018). Influence of strategic leadership on the performance of international humanitarian organizations in Kenya. International Academic Journal of Innovation, Leadership, and Entrepreneurship, 2(2), 113-135.

[11] Kairu, E. W., Wafula, M. O., Okaka, O., \& Akerele (2013). Effects of balanced scorecard on the performance of firms in the service sector. European Journal of Business and Management, 5(9), 81088.

[12] Kaplan, R., \& Norton, D. (2007). Using the balanced scorecard as a strategic management system. Harvard Business Review 87 (7/8). 150-161.

[13] Kirk, G., \& Nolan, S. B. (2010). Non-profit mission statement focus and financial performance. Non- profit Management and leadership, 20(4), 473-490.

[14] Kirkpatrick, S. A. (2017). Understanding the role of vision, mission, and values in the HPT Model. International Society for Performance Improvement, 56(3), 6-14.

[15] Kwenin, D. O., Muathe, S., \& Nzulwa, R. (2013). The influence of employee rewards, human resource policies, and job satisfaction on the retention pf employees in Vodafone Ghana Limited. European Journal of Business and Management, 5(2), 13-20. 
[16] Massingham, R., Massingham, P. R., \& Dumay, J. (2019). Improving integrated reporting: A new learning and growth perspective for the balanced scorecard. Journal of Intellectual Capital, 20(1), 60-82.

[17] Mumo, P. M. (1997). A study of theological education in Africa Inland Church-Kenya: Its historical development and its present state (Unpublished doctoral dissertation), University of Nairobi, Nairobi, Kenya.

[18] Mutia, P. M. (2015). Strategic leadership and its influence on church growth in Kenya (Unpublished doctoral dissertation). United States International University - Africa, Nairobi, Kenya.

[19] Mutuku, J. M. (2014). Strategic responses to the dynamic business environment in Kenya by Old Mutual Kenya Limited. Master of Business Administration Degree, University of Nairobi, Kenya.

[20] Mwambazambi, K. (2014). Developing transformational leadership for subSaharan Africa: Essential musicological considerations for church workers. Verbum et Ecclesia, 35(1), 19.

[21] Naidoo, M. (2015). Contested issues in training ministers in South Africa. Stellenbosch. Sun Press.

[22] Namin, H. S., \& Ebrahimpour, H. (2015). The impact of internal processes on strategy implementation on non-commercial performance of employees at Imam Khomeini relief committee. Arabian Journal of Business and Management Review (Nigerian Chapter), 3(1), 143-147.

[23] Ng'ang'a, L. W. (2018). The perceived influence of strategic leadership on organizational performance tourism government agencies in Kenya (Unpublished doctoral dissertation). Kabarak University, Nakuru, Kenya.

[24] Nkonge, D. (2013). Theological education institutions in Kenya and the future of the church: An Anglican case study. Journal of Adult Theological Education, 10(2), 147-161.

[25] Odita, A. O., \& Bello, A. (2015). Strategic intent and organizational performance: A study of Banks in Asaba, Delta State Nigeria. Information and Knowledge Management, 5(4), 60-72.

[26] Okibo, B. W., \& Masika, E. (2014). Factors affecting monitoring of the strategic plans: A case of Kenya Seed Company. Journal of Business Management, 16(4), 14-20.

[27] Omanga, D. (2019, July 13). Universities merger necessary, but we have to start right. The Standard.

https://www.standardmedia.co.ke/article/2001333686/the-pitfalls-of-rushedmerger- of-universities - accessed August 20, 2019.

[28] Ozdem, G. (2011). An analysis of the mission and vision statements on the strategic plans of higher education institutions. Education Sciences: Theory and Practice, 11(4), 1887-1894.
[29] Pandian, T. M., \& Narendran, A. (2015). Impact of financial performance indicators on profitability. International Journal of Current Research, 7(1), 12141-12149.

[30] Populova, Z. (2014). The significance of vision and mission development for enterprise in Slovak Republic. Journal of Economics, Business, and Management, 2(1), 12-16

[31] Suchanek, P., \& Kralova, M. (2015).Effect of customer satisfaction on company performance. Acta Universitatis Agriculturae et Silviculturae Mendelianane Brunensis, 63(112), 1013-1021.

[32] Szpakowski, S. (2011). Making sense of strategy in an uncertain world. Oxford Leadership Journal, 2(1), 1- 8.

[33] Thompson, A. A., Peteraf, M. A., Gamble, J. E., Stickland, A. J. (2012). Crafting and executing strategy: Concepts and cases. New York: McGraw-Hill, Irwin.

[34] Thompson, A., Peteraf, M. A., Gamble, J. E., Stickland, A. J., Jain, A. K (2013). Crafting executive strategy: The quest for competitive advantage, crafts and cases. India: McGraw Hill Education (India) Private Limited.

[35] UN-Habitant Annual Report (2016). Planning sustainable cities: Global report on human settlements 2009. Routledge.

[36] Van Vart, M. (2014). Leadership in public organizations: An introduction (2nd ed.). New York, NY: Routledge.

[37] Wheelen, T. J., \& Hunger, J. D. (2012). Strategic management and business policy: Toward global sustainability (13 ed). New York: Pearson.

\section{AUTHORS}

First Author - Munyao, Solomon. M, School of Leadership, Business and Technology, Pan Africa Christian University, P.O. Box 56875-00200, Nairobi

Second Author - Chiroma, Nathan. H. (PhD), School of Theology, Pan Africa Christian University, P.O. Box 5687500200, Nairobi

Third Author - Ongeti, Walter. J. (PhD), School of Leadership, Business and Technology, Pan Africa Christian University, P.O. Box 56875-00200, Nairobi

Email of $\quad \begin{gathered}\text { corresponding } \\ \text { solomon.munyao@pacuniversity.ac.ke }\end{gathered}$

